based on its latest report. From the report, it will be seen that, for the very modest expenditure of $£ 600,000$ during the year, investigations on food, clothing, housing, transport, etc., have produced results of general value to the health, happiness and economic well-being of man. It is a sad commentary on the state of civilization that, as a result of national animosities, the Government of a leading State and world power should spend in one year some five hundred times as much on armaments and defence as on potentially productive scientific investigations.

\section{Marble Mantelpieces from Banks's House}

BESIDEs being for thirty-six years (1821-1857), the home of the Linnean Society, No. 32 Soho Square, London, which was demolished in 1937 (NATURE, 139,280 ; 1937) was historically connected with both the Royal Society and the Royal Institution. From 1777 until his death in 1820, it was the town house of Sir Joseph Banks. Traditionally, Council meetings of the Royal Society were held there, and although this has not been confirmed, there can be no doubt that, during Sir Joseph Banks's long presidency, meetings on the business of the Society were held at the President's home. The Royal Institution was founded there at a meeting held under Sir Joseph's chairmanship in March 1799. Before it was demolished, the decorative fittings of the house were sold by auction. Two marble mantelpieces were purchased at the sale and presented by Sir Robert Hadfield, one to the Royal Society and the other to the Royal Institution. That given to the Royal Society is to be placed in the Officers' Room of the Society's apartments in Burlington House in due course. The other, it was reported to the members of the Royal Institution at the General Monthly Meeting on March 7, has now been re-erected in the Library of the Institution. An account of No. 32 Soho Square, and of the mantelpiece at the Royal Institution, which has had a most interesting history, is given on p. 437 of this issue.

\section{The Milk Problem in Great Britain}

Lieut.-Colonel C. Waley Cohen, in an article in the February issue of the Nineteenth Century and After, surveys and discusses the problem of the milk supply in Great Britain. He points out that the milk supply of England and Wales has been reviewed by no fewer than five Royal Commissions and Committees during the last twenty years, and has been the subject of several departmental orders and of legislation during the same period. All this has rendered the farmers nervous and the public bewildered, with the result that the consumption of liquid milk in Great Britain is low, and the price high, as compared with some other countries. A change has also taken place in the method of distribution and supply, for prior to 1900 supply of liquid milk to the consumer was mainly direct, by 1923 producer-retailers supplied only 40 per cent, and to-day only 20 per cent, of the total requirements, the remainder being bulked, often conveyed long distances, and then distributed. Bulk- ing of liquid milk is the key to many of the difficulties surrounding the milk supply: it gives rise to the major problem of milk-borne diseases, and was the proximate cause of the necessity for, and creation of, the Milk Marketing Board. The Great War also created an impetus to the importation of cream, butter, cheese and other milk products from the Dominions and foreign countries.

BULKING of milk largely increases the danger from milk-borne diseases, for a small addition of infected milk will infect the whole of the milk to which it has been added, amounting, perhaps, to 2,000 gallons or more. This, together with the time that elapses between the milk leaving the producer and reaching the consumer, renders some form of heat treatment necessary. In the case of bulked milks, efficient pasteurization is therefore desirable, and a scientific system of pasteurization should be enforced. The risk of milk-borne disease in rural, and in less congested urban, areas is low, as bulking is rare. Efficient pasteurization in small urban, and in rural, areas is expensive, and would deprive these areas of the reduction of $4 d,-6 d$. per gallon in retail milk price which they now enjoy. The grading of milk, and the accredited scheme, receive some criticism. Colonel Cohen desires the establishment of some better 'concordia' on the medical side between experts, practitioners, medical officers of health, bacteriologists and veterinarians; on the commercial side between producers, distributors and manufacturers; and generally between all these and administrative officials. Nothing should be done to restrict or dis. courage the production of milk in Great Britain, for the industry is outstanding in the agricultural economy of the country, and the income from milk and dairy produce forms no less than 28 per cent of the nation's agricultural income. Finally, it is sug. gested that there is much scope for the establishment of a permanent Milk Commission, with a real administrative competence.

\section{Films and Folk-Lore}

IT is remarkable that little use has been made in Great Britain of the cinematograph for recording systematically the survivals, now rapidly diminishing in number, of customs and festivals formerly observed among the people. British anthropologists were not slow to appreciate the possibilities of the cinematograph in field work : and more than thirty years ago the Daniels-Seligman anthropological expedition to New Guinea secured some striking records, as also did the late Sir Baldwin Spencer in the Northern Territory of Australia in an illuminating series of films of native ceremonial dances shown in London in 1914. In the home-field, however, notwithstanding more favourable conditions, this potential auxiliary of scientific study of folk-custom has been sadly neglected, although the commercial film has shown appreciation of the spectacular value of brief episodes of folk-dance and ceremonial for the news-reel. Familiar as these were, the value to the student of the film taken for purposes of scientific record only, 
and not as part of a public performance, was brought out by some of the Continental films, especially the instrumental films, shown at the International FolkDance Festival in London in 1935, which came as something of a revelation. It is satisfactory to note, therefore, that an attempt is to be made to remedy the deficiency in the equipment of folk-lore studies in Great Britain by an endeavour to secure a record of folk survivals, which will include not only folkdances and folk-customs, but also folk-crafts, which are in danger of extinction. The proposal, it is announced in a communication to The Times of March 7, is put forward on behalf of the Folklore Society, the English Folk-Dance and Song Society and the National Film Library. Sound films, it is also suggested, might be made of such activities as the almost extinct art of hand-bell ringing and of folk-dances in situ. The expense of carrying out such a scheme obviously will be considerable, and it is hoped that private benefaction will be forthcoming. In view, however, of the scientific and historical interest of local custom, whether ceremonial or industrial, the local museum, especially where an attempt is made to illustrate local antiquity and history at all adequately, might regard a subsidy in aid of a local film as a legitimate charge on its financial resources.

\section{The New Commonwealth}

THE eighth in the series of broadcast talks on "The Way of Peace" was given on March 3 by Lord Davies, who spoke on the New Commonwealth. This is, he said, a voluntary, international society, composed of members living in forty-six different countries, who have banded themselves together in order to enlist the support of public opinion for the establishment of two institutions-an equity tribunal or commission, and an international police force-as part of the permanent machinery of the League of Nations. No Government could carry on for a single week unless it possessed institutions capable of effecting changes in its laws, and the means of upholding them. How then can we expect the League to inaugurate the rule of law if its members refuse to give it those institutions essential for carrying out the responsibilities they have entrusted to it? War can only be prevented by establishing international law and order on the same principles, and by the same methods, which have been successfully applied in the development of every civilized community. Lord Davies then dealt briefly with the two institutions in the New Commonwealth programme. The task of the equity tribunal would be to deal with any disputes which the League Council fail to settle by the existing procedure of negotiation and conciliation. The aim of the second point of the New Commonwealth programme, said Lord Davies, is the substitution of co-operative for competitive armaments. This can best be done by means of a police force under the control of the international authority. Only in this way, he considers, can the rule of law be established and the downfall of Western civilization averted.

\section{Gliding and Soaring Flight}

AT the Friday evening discourse at the Royal Institution on March 4, Prof. D. Brunt discussed "Gliding and Soaring Flight". As the modern sailplane has a sinking speed in still air of 2-3 ft. per second, it will soar in an ascending current which rises faster than this modest limit. Three types of ascending currents occur in the atmosphere. Where the wind blows against the slope of a hill, it follows the contour of the ground, and if the air rises faster than the sinking speed of the sailplane, the latter can soar over the hill slope. Such a flight of 9 hours 48 minutes was carried out at the international competitions in Germany last summer, by Messrs. Fox and Murray in a Falcon III two-seater. When the air near the ground is heated until the rate of fall of temperature with height exceeds $5 \cdot 6^{\circ} \mathrm{F}$. per $1,000 \mathrm{ft}$., the air becomes unstable, and currents of warm air rise, and, if damp, give rise to clouds. Under the cumulus clouds then formed, the sailplane can mount in the rising air. When the wind increases with height the clouds are in long rolls, which have ascending air under their whole length, and in this air the sailplane can soar along the whole length of the cloud. In the rear of a depression, at the cold front, where the cold air pushes under warm air and forces it to rise, the rate of ascent of the warm air is often sufficient to enable a sailplane to soar. The British record for distance of soaring flight is 104 miles and was set up by Mr. Philip Wills. The world's record for distance, 405 miles, was set up by a Russian pilot in May, 1937.

\section{Asymmetric Sideband Broadcasting}

Mr. P. P. Eckersley in a paper read to the Institution of Electrical Engineers on March 2 said that the present methods of working permit few, except local radio broadcasting stations to be received without interference from other transmitters operating in contiguous frequency channels, unless the upper frequencies of modulation of the wanted station are severely attenuated. In this case the reproduction lacks intelligibility and naturalness. This can be mitigated without introducing audible harmonic distortion by utilizing the asymmetric sideband system of transmission to cut away with the aid of electrical filter circuits part of one sideband of the frequency spectrum radiated. In a previous paper, the author has shown how 'asymmetry', either of phase or of magnitude, between two sideband components is related to harmonic distortion. It is proportional to depth of modulation. He proved that as the sideband frequency becomes more and more removed from the carrier frequency, it may be more and more attenuated while the distortion can be made to remain constant and small. The author suggests that it is better to face the occasional minute deteriorations in quality given by the asymmetric system than to suffer from the continuous hissing and splitting sounds brought about by existing inter-station interference. The public insists that the radio-set exists to give pleasure. The attention that a user gives to a programme is de- 